\title{
Geography and social policy: spatial divisions of welfare
}

\section{John Mohan}

Geography Department, University of Portsmouth, Buckingham Building, Lion Terrace, Portsmouth PO1 3HE, UK

\section{Introduction}

The case for a geography of welfare services cannot be made simply by reference to the observation that there are spatial disparities in life chances. One obvious reaction would be that a geographical perspective on this is no more than mapping the outcomes of social policy, and, looking at the British academic literature in that discipline, there is little evidence (at least from citations) that geographical work has had much of an impact. Reviewing work within political science, Pierson (1998) noted that the welfare state was no longer the preserve of sociologists, but did not evaluate the contribution of geographers. Indeed, if Powell and Boyne (2001) are to be believed, geography has had little of value to say about the welfare state. I agree with their point that there has never been an explicit spatial dimension - other than perhaps a vaguely specified notion of territorial justice - to welfare policies. However, they then advance a straw person argument. They are mistaken in suggesting that many geographical studies simply 'point out that inequality exists', use 'simplistic notions of equality' or assume that all geographical variations constitute defects. Admittedly, their review relies on some rather elderly geographical texts, mainly on the human geography of the UK, but I argue here that much has already been done to rectify the weaknesses they claim to discuss. Indeed they might usefully have consulted Pinch $(1997 ; 1998)$ which emphasized the role of 'geographical imaginations' in understanding the diverse 'worlds of welfare' and which makes the case for a 'spatially-aware social policy'. The aim of this review is to consider both the validity of the argument of Powell and Boyne (2001) and the extent to which Pinch's challenges have been taken up. First, there is a review of literature on the impacts of globalization on welfare and the character of emergent transitions in the welfare state, raising questions about the character of supranational welfare 'regimes' and also about the diversity of political responses within 
those regimes. Second, there is a discussion of literature tracking the local impacts of welfare reforms, albeit from several quite different methodological frameworks.

\section{Worlds of welfare: national and international convergence}

The need for a geographical perspective has been highlighted because welfare states are now confronted by circumstances not anticipated at their inauguration. Three such circumstances, and their consequences, are of particular relevance: the impacts of globalization on the scope for manoeuvre of nation states; the correspondence (or otherwise) between transitions in the organization of production and arrangements for delivering welfare; and the changing social landscape against which welfare policies are implemented. Given the uneven impacts of these processes, a geographical perspective is almost a necessity, as an essential part of an analysis of the welfare state which is sensitive to context.

One view of globalization sees it as an inevitable process, to which nation states must submit. The vision of a Dutch auction is easily conjured up here, but there are arguments about whether there is indeed 'no alternative' or whether governments are complicit in an ideological war of position whereby it suits them to act as if that is the case (compare Hay, 1998; Pierson, 1998; Taylor-Gooby, 1997). If nation states indeed had no choice but to submit to the pressures of globalization, we ought to find evidence of it in convergence, between states, towards reduced levels of welfare expenditures and possibly towards similar arrangements for welfare delivery. The evidence for this has been reviewed by Pierson (1996), Rieger and Liebfried (1998) and Clayton and Pontusson (1998). Pierson (1996) made a case for the resilience of the welfare state in the face of external pressures, arguing that the welfare state represented the status quo, such that cutbacks incurred high electoral costs. Clayton and Pontusson (1998) were less optimistic; while levels of spending may not have changed, much of this was against the background of growing inequality, generating higher needs, and it masked the differential impact of pro-competitive policies within the public sector. The latter are to be explained in terms of a cross-class coalition of workers and employers in the export and multinational sectors (Clayton and Pontusson, 1998: 96-97) concerned to contain the upward pressures on domestic costs generated by large public sectors. Rieger and Liebfried (1998), by contrast, claim that the welfare state is a necessary part of integration into a global economy and indeed that the existence of welfare states made economic openness possible (p. 375), by coping with the social consequences of a global economy. These analyses alert us to the diversity of responses to globalization (see also von Mahs, 2001), and to the possibility that future social policy regimes will incorporate a greater supranational dimension (e.g., via the EU) and/or a greater local dimension (Leibfried, 2000).

Social policy analysts have tended to frame discussion of welfare regimes in terms of broad typologies. Esping-Andersen is one of the best-known scholars in this context. Arguing that the tendency to presume a 'largely convergent global process impairs our analytical faculties', his latest study (1999) reviews the prospects for different sorts of welfare regimes. He argues that a 'postindustrial welfare optimum' requires some kind of 'mobility guarantee' so that it is capable of 'guaranteeing all citizens against entrapment', whether of a social or spatial character. Esping-Andersen does not spell 
out in detail what such guarantees would look like. However, the novel comparative study by Goodin et al. (2000) of welfare regimes, drawing on comparable panel data, indicates that social democratic regimes have generally been most successful in meeting these aspirations. Reviewing recent work on European social policy, Clasen (2002: 71) notes a shift from the 'somewhat static discourse on regime boundaries towards . . . a more dynamic understanding of regimes and an interest in analysing change'.

In addition to globalization, transitions in the organization of production appear to have, as their correlates, consequences for the organization of welfare. There is an argument that welfare regimes are moving from the Keynesian welfare national state (KWNS) towards a Schumpeterian workfare postnational regime (Jessop, 1999). This putative transition has attracted a great deal of attention from geographers researching such topics as workfare policy (Peck, 2001), training policy in the UK (Jones, 1999), or hospital restructuring in New Zealand (Barnett, 2000). One of the core premises of such regulationist work is that (while what replaces Fordism is disputed) there is emerging a spatial reconfiguration of the production process, implying greater local differentiation in local labour markets. As Pierson (1998) argues, it is not therefore surprising that such theoretical frameworks have greatest purchase on welfare-to-work policies. It is less clear that the same can be said of, say, health care or education.

A key methodological challenge is that of interpreting change and identifying novelty in social policy. With a longer historical frame of reference, we might emphasize continuity as well as change. Taking the regulation and governance of hospital care in the UK (Mohan, 2002), it is not difficult to demonstrate the application of commercial criteria to public-sector decision-making, anticipating the contemporary Private Finance Initiative by over 60 years. Likewise, in the 1930s British local authorities were frequently reminded that excessive welfare expenditures would have ramifications for the level of property taxation, thus potentially deterring private investment. This seems a clear illustration of the subordination of social policy to economic policy. Furthermore, the era of hierarchical, state planning was never as monolithic, or characterized by top-down bureaucracy, as its critics imply. Its successor, the pro-competition era ushered in from 1991, either retained, or hurriedly reinvented, strong elements of 'planning'. These comments do not in any sense invalidate the ambitions of regulationist-inspired analyses, but they caution against premature identification of a novel welfare regime. In particular, we might recall the distinction made by Offe (1984) between a contradiction and a dilemma, the latter denoting an administrative problem and the former signifying a structural incompatibility between the preconditions for and the results of a mode of production. For example, while neoliberal regimes may encounter various blockages, and while they may tend to greater geographical variability, the former may be overcome while the latter may be desirable. Tensions, ambiguities and implementation difficulties should not be taken as harbingers of structural incompatibilities, and policy experimentation does not denote a new set of institutional arrangements. This is basically the point made by Bennett (2000) in his review of Jones (1999). Likewise, if there is little doubt that states have been 'hollowed out', historians would remind us that they first of all had to be 'filled in' and that large-scale centralized welfare bureaucracies were in some respects short-lived (Lowe and Rollings, 2000).

The process of globalization has three further effects on the geographies of welfare. First, it is associated with corporate demands for deregulation and privatization under 
the auspices of GATS and the WTO. The reason for this is to be found in diminishing returns from manufacturing and the perceived possibilities for profit in the service sector. Here, multinational service corporations, some with a long track-record of seeking to exploit variations in regulatory standards, have been pressing governments to open public services up to greater competition and private financing. Iriart and Waitzkin (2000) and Pollock and Price (2000) are among those concerned that this will lead to the export of inappropriate models for welfare provision, with socially regressive consequences. Private companies are most likely to segment services, cherrypicking the parts of the system with greatest potential for profit (Crouch, 2001; Leys, 2001). Second, there has been a process of international exchange of ideas in areas such as welfare-to-work (Peck, 2001; Peck and Theodore, 2000) and health care. Some would now contend (Crouch, 2000) that a global dominant class has emerged in the guise of cadres of management consultants and policy advisers, with enormous potential to shape the terms of reference of political debate. The effect, it is argued, is that we are now in a 'post-democratic' era, in which all interests except those of privileged élites are marginalized. Third, widening income disparities are a result of the shift towards services and high-technology industry, but they are also an obstacle, in that they may tend to create a constituency with more of a vested interest in the status quo.

\section{Local geographies: markets, voluntarism and decentralization}

Descending from the terrain of discussing macro-level convergence or divergence in welfare systems, what contribution has been made to the analysis of the local impacts of changes in the welfare state? The first point to make is that an arbitrary focus on the local would miss the connections between different scales of analysis. Merrett (2001) demonstrates the way in which cross-scale investigations help understand different local contexts, while Cope (2001) points to the ways social service organizations are mediating institutions between scales (e.g., between states, localities and their clients).

There have, of course, been numerous studies of the local impacts of social policies. Much attention has been given to welfare-to-work. Peck (2001) has analysed the local geography of welfare reform policies, principally in Britain, Canada and the USA, and Jones (1999) has discussed the potentially degenerative and regressive characteristics of marketization of welfare policies in his work on Training and Enterprise Councils in the UK. There has been a sustained interrogation of the local impacts of welfare to work by Martin, Sunley and Nativel (Sunley et al., 2001; Nativel et al., 2002), on the New Deal for Young People in the UK. This nicely illustrates the tensions between localism and centralism implicit in welfare policies, and explores the implementation difficulties posed by the complex geographies of local labour markets.

There is also a growing corpus of research into the effects of pro-market policies on other welfare services. In their study of hospital restructuring in Ontario, Hanlon and Rosenberg (1998; see also Hanlon, 2001) accuse the new public management of a 'denial of geography' by adopting one-dimensional yardsticks for evaluating hospital 'performance', to the neglect of contextual explanations of that performance. Exworthy (1998) shows, in contrast, that the impact of market reforms in the English NHS was constrained by local 'embeddedness': established relationships between communities and hospitals meant that the pattern of referrals to hospital changed to only a limited 
extent. As for other sectors, there are detailed studies from Los Angeles which deal with policy towards the homeless (Law, 2001) and the spatial configuration of income support offices (DeVerteuil et al., 2002). Other relevant studies include Smart and Smart (2001) on the implications of Chinese welfare reform for local citizenship, and Thomson's (2002) work on regional variations in social service provision in postCommunist Russia. Kearns and Joseph (2000) also document the effects of urban restructuring on deinstitutionalization policies in New Zealand, demonstrating the problems of accommodating marginalized groups in a context of rapid urban restructuring. Morrison and Waldegrave (2002) track the impacts of welfare reform on intraregional migration of beneficiaries, questioning the simplistic notion that some areas become 'welfare magnets' for the poor. Wolch and Dinh (2001) argue that a 'new Poor Law' has come into being, in which localities (rather than central states) are responsible for managing their own impoverished populations.

The impact of markets on the geography of education has also provoked considerable dispute. In the guise of a technical debate about how to measure and analyse segregation between schools, an ongoing exchange between Gibson and Asthana (1998; 2000a; 2000b; 2000c) and Gorard, Taylor and Fitz (Gorard and Fitz, 1998; 2000; Gorard, 2000; Taylor and Gorard, 2001) is of considerable importance. The questions they address - are British schools becoming more, or less, socially segregated and, if so, what causes this and at what spatial scale are the effects felt? - have implications not only for the prospects of children but for future levels of residential segregation and social solidarity.

There is little doubting the existence of the 'profound social gradient that underpins variations in school performance' (Gibson and Asthana, 2000a: 1268). This raises questions about how to distinguish between 'schools which do well (or poorly) in spite of their circumstances from those which do well (or poorly) because of their circumstances' (Gibson and Asthana, 1998: 278, emphasis in original). This requires appropriate measures of the socio-economic characteristics of school populations, and because schools do not serve defined catchments, Gibson and Asthana (2000a) have developed measures based on linking the addresses of pupils to small-area census data. They show that the measures of the socio-economic status of school populations derived in this way provide a greatly superior statistical explanation of the examination results of schools than is the case for measures such as the proportion of children on free school meals (a means-tested benefit available to (but not always taken up by) families on low incomes).

In terms of cross-sectional analyses of school performance this work is a considerable achievement. However, the more controversial debate sparked off by such analyses concerns whether socio-economic segregation between schools has been increasing and whether, therefore, observed changes in the 'performance' of schools are in part a function of the changing social composition of their pupils. Gibson and Asthana (2000b) argue that this is so. However, Gorard and associates (e.g., Gorard and Fitz, 1998; 2000; Taylor and Gorard, 2001) contest this. They rely on a variant of the index of dissimilarity; they calculate the number of children in a Local Education Authority who would have to change schools in order that each school would have an identical proportion of children on free school meals. They claim, for LEAs in England and Wales in the period since 1988, that overall segregation between schools has been declining, so that schools are becoming more mixed in their intakes. They show that in only a minority of LEAs 
did segregation increase over the 1989-97 period, while many LEAs experienced a substantial proportionate decline.

Gibson and Asthana argue, in contrast, that the relationship detected by Gorard and colleagues is artefactual, because they are documenting a period in which the proportion of pupils in receipt of free school meals rose; it is therefore inevitable that a smaller proportion of the school population would have to move to achieve parity in the distribution of the disadvantaged. The proportions of pupils eligible for FSM would also vary according to the differential regional impact of economic changes. They also dispute the scale at which school markets operate. It is not meaningful to contend that, in large rural LEAs, there is much choice realistically available, in contrast to densely populated urban LEAs, so Gibson and Asthana prefer to define local school markets by comparing each school in their sample with each of its four nearest neighbours. While in a sense arbitrary, it may be considered a more realistic approximation to the environment faced by parents when choosing between schools. On this basis they contend (Gibson and Asthana, 2000b) that initially high-ranking schools are both improving their GCSE performance fastest, and also drawing to themselves the most socially advantaged pupils. If correct, this finding lends substantial weight to the case that market forces, parental choice and school polarization are causally intertwined. Taylor and Gorard (2001: 1829) contend that 'schools remain socially divided chiefly because of the socially-divided nature of housing', which is valid, but the point of the work of Gibson and Asthana is that market forces appear to be reinforcing social divisions, albeit for a short timescale. The debate is a somewhat fractious one, with Taylor and Gorard (2001) appearing to continue with their own preferred approach while ignoring explicit criticisms of the methodology underpinning them. The matters at issue might appear to be technical ones relating to index construction and an appropriate scale for analysis, but they could not be of greater significance given the connections between housing and school markets.

Much of the work reviewed thus far relates to welfare services provided by the public sector, but commercial and voluntary provision have not been ignored. A widely accepted argument is that, as well as relying on market forces to allocate resources, states have sought to offload responsibilities for welfare onto individuals and communities. Some would contend that we now have a 'DIY welfare state' (Klein and Millar, 1995) because economic prosperity has placed many more individuals in a position to purchase their own welfare services. Thus, Cebulla (1999) and Sunley (2000) have explored growth in private insurance against unemployment, and pension provision respectively, while Taylor (2001) has updated Bradford's (1995) earlier work on the private-state continuum in British schooling. There are concerns that such processes may result in a 'secession of the successful' from the public sphere; Boudreau and Keil (2001) have considered the implications for suburban communities around Los Angeles, albeit without explicitly drawing out the implications for the welfare state. Burchardt et al. (1998) have charted at a national level the segment of the British population which uses combinations of private welfare services (primarily health and education) and have concluded that this group does not represent a distinct 'overclass', but there remains scope for a geographically differentiated analysis of this topic.

Voluntarism has also attracted greater attention. Bryson et al. (2002) studied variations in availability of almshouse accommodation in the UK and the recent historical work of Gorsky et al. (1999; 2002; see also Mohan, 2003) maps what Finlayson 
(1994) termed the 'moving frontier' between the voluntary sector and the state. These build on a tradition arguably initiated by Wolpert's work on the voluntary sector in the USA. His most recent publication constituted an effective warning against the likely consequences of the neoconservative 'contract with America' being peddled in the mid1990s by the Republican right (Wolpert, 1996). Merrett's (2001) study of non-profit organizations in Illinois raises serious questions about the likely effects of a shift of welfare responsibilities from the state to the non-profit sector. In addition to work on voluntary institutions, there are now emerging studies which show the uneven results of reliance on informal and community-based forms of care, including Milligan (1998; 2000a) on informal care in Scotland, Robson (2000) on the role of children in caring for adults in Zimbabwe, Joseph and Hallman (1998) on the effect of distance on the provision of informal support to elderly relatives, and del Casino (2001) and Brown (1997) on support groups for AIDS and HIV in Thailand and the USA respectively. All of these draw attention to spatial mismatches between the availability of informal sources of support and the distribution of those in need of it. Also implicit in this literature is the notion that the distribution of voluntary effort is not some geographically variant ethical orientation, but is a function of institutional structures and entails a two-way relationship with the state. Thus Healy (2000) is able to show that variations in blood donation arise from 'embedded altruism': collection regimes produce their donor populations by providing differential opportunities to donate blood (see also Grubesic, 2000, for a geographical study of organ donation registers). Mitchell (2001) criticizes the cooptation of voluntary agencies into a neoliberal agenda for welfare restructuring in Vancouver, a point which Milligan (2000b) would endorse on the basis of her study of Scottish voluntary organizations. The burgeoning literature on social capital, which sees social capital as being generated by voluntary activity, is recognizing the contextual and institutional - and thus geographical - influences on its formation (Mohan and Mohan, 2002; see also Putnam, 2000).

This focus on the local is also reflected in new work drawing on the cultural turn within geography. Although a focus on identity and difference has a long pedigree in social policy (Taylor, 1998), the novel contribution here may be in drawing attention to the symbolic elements of the landscapes of the welfare state. Work drawing on cultural geography has shed light on the attachments people have for symbolic elements of welfare systems (such as hospitals: Moon and Brown, 2001) or has treated welfare as a landscape of consumption (Kearns and Barnett, 1999). There is also work which has explored the problems of finding space for 'others' within urban landscapes undergoing rapid socio-economic change, as evidenced in the recent theme issue of Health and Place on 'post-asylum geographies' (Philo, 2000). Analyses from such perspective seem to have much to offer in terms of emphasizing how landscapes of inequality and welfare are discursively constructed. Conservative critics have for many years emphasized the failings and fecklessness of individuals rather than structural inequalities, but a relatively recent development has been the construction of places as alien territory, and as locations in which normal social codes break down. This is carefully analysed in Haylett's (2001a; 2001b; 2003) work on welfare policy in Britain. She shows how a discourse of social exclusion is constructed which diverts attention from material inequality towards the failings of social groups located in particular spatial contexts (see also Hastings, 1999; Kleinman, 2000). In turn, this discursive construction serves to restrict the scope of justifiable intervention to small-scale carefully 
targeted policies predicated on a new relationship between welfare and space. In the UK this has taken the form of a succession of zonal policies focused on enhancing 'community capacity' through self-help and partnership efforts rather than injections of public funds. The irony is that the targeted localities are in the state they are in precisely because they lack such partnerships (Mohan, 2000). There is little doubt, in Britain and elsewhere (e.g., Glasmeier, 2002), that poverty has persistently been concentrated in particular places, and that this has been a justification for spatially focused policies. However, this does not automatically mean that area effects exist. Other social scientists have recently expressed scepticism as to whether such effects can actually be detected, because of problems of endogeneity. Most people have a degree of choice of residential location, and this can confound efforts to establish the effects on individuals of the area in which they live (see the review by Dietz, 2000). However, the recent work of the Centre for the Analysis of Social Exclusion, at the London School of Economics, offers a convincing case for spatial targeting as a complement to universal welfare programmes (Hills et al., 2002).

\section{Conclusions: terms of engagement}

In this journal, and elsewhere, there has been concern about the normative implications of current trends in human geography, and about whether (and on what terms) greater engagement with public policy might be desirable. The work reviewed here is very much part of that debate. Returning to the strictures of Powell and Boyne (2001), quoted at the beginning of this piece, what contribution has geography made to the analysis of social policy? Three possible answers suggest themselves on the basis of the foregoing. At the most basic level, there are some very good empirical studies of the extent to which welfare policies have had an uneven impact. Second, there have been studies which emphasize the importance of context - the difference that space makes to the operation of welfare systems. Cope (2001) contends that this is crucial because it takes geographical studies beyond narrow demonstrations of spatial variation. Third, the discursive construction of landscapes of inequality and welfare institutions has highlighted the importance of representations of places and their inhabitants. There remains the question of the what kind of spatial strategy could be constructed for the welfare state.

There are several options on offer here. Smith (2000: 206, 213) argues for enhancing social cohesion, which would be facilitated by mitigating the impacts of market forces. This is consistent with the views of commentators who argue that societies with greater social cohesion are more successful (Putnam, 2000). How this state of affairs might be brought about remains undiscussed in Smith's work. In respect of the welfare state, there have been various proposals for an alternative to state bureaucracy or unfettered markets. These include variants on the theme of decentralized forms of associative democracy (see the debate between Stears, 1999, and Hirst, 1999), or the 'third way', combining a minor degree of redistribution with an apparently more activist government (Giddens, 1998; Mouzelis, 2001), while communitarian stakeholding prescriptions have been ably criticized by Low (1999). There is also an emergent 'green' critique of the welfare state (Pierson, 2001).

All of these face the problem that the socio-economic landscape, against which 
welfare policies are implemented, has changed - and not in a progressive direction. Baldwin (1994) argued that explanations of welfare state development should be cast less in terms of pressure from the working class and more in terms of what the prosperous majority are willing to share. Trends towards residential segregation may mean a growing imbalance between tax receipts from places and public expenditures on places, of the kind described for Australia for Baum et al. (2000), with prosperous localities bearing a rising share of the tax burden while receiving a relatively low share of public spending. If this is the case then, as Pahl (2001) suggests, we need a renewed understanding of the attitudes of the 'comfortable majority' if further erosion of citizenship is to be prevented (Turner, 2001). Otherwise we can probably anticipate greater tendencies towards privatization and towards the greater penetration of markets in the residual public sector, such that, as Iris Marion Young (1990: 72, quoted in Christopherson, 1994) argued some years ago, 'normative claims to justice become selfish claims to desire'. Christopherson (1994) argues that 'the result is a limited sphere of public action for larger social purposes'.

\section{Acknowledgements}

Thanks are due to several people who kindly drew my attention to relevant reading and/or supplied offprints or copies of work in progress. These are Ross Barnett, Meghan Cope, Alex Gibson, Brendan Gleeson, Neil Hanlon, Chris Haylett, Ron Martin, Christine Milligan, Jamie Peck, Martin Powell, Bob Stimson and Jennifer Wolch.

\section{References}

Baldwin, P. 1994: The politics of social solidarity: class bases of the European welfare state. Cambridge: Cambridge University Press.

Barnett, R. 2000: Rationalising hospital services: reflections on hospital restructuring and its impacts in New Zealand. New Zealand Geographer 56, 4-20.

Baum, S., Stimson, R., Mullins, P. and O'Connor, K. 2000: Welfare dependency in communities within Australia's metropolitan regions. People and Place 8(3), 28-37.

Bennett, R. 2000: Review of New Institutional Spaces by M. Jones. European Urban and Regional Studies 7, 85-86.

Boudreau, J.-A. and Keil, R. 2001: Seceding from responsibility? Secession movements in Los Angeles. Urban Studies 38, 1701-31.

Bradford, M. 1995: Diversification and division in the English education system. Environment and Planning A 27, 1595-612.

Brown, K., Kenny, S., Turner, B. and Prince, J. 2001: Rhetorics of welfare. London: Macmillan.

Brown, M. 1997: RePlacing citizenship: AIDS, activism and radical democracy. New York:
Guilford Press.

Bryson, J., McGuinness, M. and Ford, R. 2002: Chasing a 'loose and baggy monster': almshouses and the geography of charity. Area 34, 48-58.

Burchardt, T., Hills, J. and Propper, C. 1998: Private welfare and public policy. York: Joseph Rowntree Foundation.

del Casino, V. 2001: Healthier geographies: mediating the gaps between the needs of people living with HIV and AIDS and health care in Chiang Mai, Thailand. Professional Geographer 53, 407-21.

Cebulla, A. 1999: A geography of insurance exclusion: perceptions of unemployment risk and actuarial risk assessment. Area 31, 111-22.

Christopherson, S. 1994: The fortress city. In Amin, A., editor, Post Fordism: a reader, Oxford: Blackwell.

Clasen, J. 2002: Modern social democracy and European welfare state reform. Social Policy and Society 1, 67-76.

Clayton, R. and Pontusson, J. 1998: Welfare-state 
retrenchment revisited: entitlement cuts, public sector restructuring, and inegalitarian trends in advanced capitalist societies. World Politics 51, 67-98.

Cope, M. 2001: Between welfare and work: the roles of social service organisations in the social regulation of labour markets and regulation of the poor. Urban Geography 22, 391-406.

Crouch, C. 2001: Coping with post-democracy. London: Fabian Society.

Dietz, R. 2000: Estimation of neighbourhood effects in the social sciences. Working Paper 00-03, Urban and regional analysis initiative, Ohio State University (available online at http: / / cura.osu.edu/research/publications / data/0003NeighRev01.PDF)

Esping-Andersen, G. 1999: Social foundations of post-industrial economies. Oxford: Oxford University Press.

Exworthy, M. 1998: Localism in the NHS quasimarket. Environment and Planning C 16, 449-62.

Finlayson, G. 1994: Citizen, state and social welfare in Britain, 1830-1990. Oxford: Clarendon.

Gibson, A. and Asthana, S. 1998: Schools, pupils and exam results: contextualising school performance. British Educational Research Journal 24, 269-82.

- 2000a: Estimating the socio-economic characteristics of school populations with the aid of pupil postcodes and small-area census data. Environment and Planning A 32, 1267-85.

- 2000b: Local markets and the polarisation of public-sector schools in England and Wales. Transactions, Institute of British Geographers, NS $25,309-19$.

- 2000c: 'What's in a number? A commentary on Gorard and Fitz's 'Investigating the determinants of segregation between schools'. Research Papers in Education 15, 133-53.

Giddens, A. 1998: The third way: the renewal of social democracy. Cambridge: Polity Press.

Glasmeier, A. 2000: One nation, pulling apart: the geographical basis of persistent poverty in the USA. Progress in Human Geography 26, 155-74.

Gleeson, B. and Kearns, R. 2001: Remoralising landscapes of care. Environment and Planning $D$ $19,61-80$.

Goodin, R., Headey, B., Muffels, R. and Dirven, H. 2000: The real worlds of welfare capitalism. Cambridge: Cambridge University Press.

Gorard, S. 2000: Here we go again: a reply to 'what's in a number' by Gibson and Asthana. Research Papers in Education Policy and Practice $15,155-62$.

Gorard, S. and Fitz, J. 1998: The more things change: the missing impact of marketisation. British Journal of the Sociology of Education 19, 365-76.

- - 2000: Investigating the determinants of segregation between schools. Research Papers in Education Policy and Practice 15, 115-32.

Gorsky, M., Mohan, J. and Powell, M. 1999: British voluntary hospitals, 1871-1938: the geography of provision and utilisation. Journal of Historical Geography 25, 463-82.

- 2002: The financial health of hospitals in inter-war Britain. Economic History Review LV, 533-57.

Grubesic, T. 2000: Driving donation: a geographic analysis of potential organ donation in the state of Ohio. Social Science and Medicine 51, 1197-210.

Hanlon. N. 2001: Hospital restructuring in smaller urban Ontario settings: unwritten rules and uncertain relations. Canadian Geographer $45,252-67$.

Hanlon, N. and Rosenberg, M. 1998: Not-so-new public management and the denial of geography: Ontario health-care reform in the 1990s. Environment and Planning C 16, 559-72.

Hastings, A. 1999: Analysing power relations in partnerships: is there a role for discourse analysis? Urban Studies 36, 91-106.

Hay, C. 1998: Globalisation, welfare retrenchment and the 'logic of no alternative'. Journal of Social Policy 27, 525-32.

Haylett, C. 2001a: Modernisation, welfare and 'third way' politics: limits to theorizing in 'thirds'? Transactions of the Institute of British Geographers, NS 26, 43-56.

_ 2001b: Illegitimate subjects? Abject whites, neoliberal modernisation, and middle-class multiculturalism. Environment and Planning $D$ 19, 351-70.

2003: Culture, class and urban policy: reconsidering equality. Antipode 35(1), in press.

Healy, K. 2000: Embedded altruism: blood collection regimes and the European Union's donor population. American Journal of Sociology 105, 1633-57.

Hills, J., Le Grand, J. and Piachaud, D., editors 2002: Understanding social exclusion. Oxford: Oxford University Press.

Hirst, P. 1999: Associationalist welfare: a reply to Marc Stears. Economy and Society 28, 590-97. 
Iriart, C. and Waitzkin, H. 2000: How the United States exports managed care to Third World Countries. Monthly Review 52(1), 21-35.

Jessop, B. 1999: The changing governance of welfare: recent trends in its primary functions, scale and modes of coordination. Social Policy and Administration 33, 348-59.

Jones, M. 1999: New institutional spaces: TECs and the remaking of economic governance. London: Jessica Kingsley.

Joseph, A. and Hallman, B. 1998: Over the hills and far away: distance as a barrier to the provision of assistance to elderly relatives. Social Science and Medicine 46, 631-40.

Kearns, R. and Barnett, J. 1999: To boldly go? Place, metaphor and the marketing of Auckland's Starship Hospital. Environment and Planning D 17, 201-26.

Kearns, R. and Joseph, A. 2000: Contracting opportunities: interpreting post-asylum geographies of mental health care in Auckland, New Zealand. Health and Place 6, 159-69.

Klein, R. and Millar, J. 1995: Do-it-yourself social policy. Social Policy and Administration 29, 303-16.

Kleinman, M. 2000: Include me out? The new politics of place and poverty. Policy Studies 21, 49-62.

Law, R. 2001: 'Not in my city': local governments and homelessness policies in the Los Angeles Metropolitan Region. Environment and Planning C 19, 791-815.

Leibfried, S. 2000: National welfare states, European integration and globalisation. Social Policy and Administration 34, 44-63.

Leys, C. 2001: Market-driven politics. London: Verso.

Low, M. 1999: 'Their Masters' Voice': communitarianism, civic order, and political representation Environment and Planning A 31, 87-111.

Lowe, R. and Rollings, N. 2000: Modernising Britain 1957-64: a classic case of centralisation and fragmentation? In Rhodes, R., editor, Transforming British Government, vol I: changing institutions, Basingstoke: Macmillan, 99-118.

von Mahs, J. 2001: Globalisation, welfare state restructuring and urban homelessness in Germany and the USA. Urban Geography 22, 457-81.

Merrett, C. 2001: Declining social capital and non-profit organisation: consequences for small towns after welfare reform. Urban
Geography 22, 407-23.

Milligan, C. 1998: Pathways of dependency: the impact of health and social care restructuring the voluntary experience. Social Science and Medicine 46, 743-53.

—_ 2000a: 'Bearing the burden': towards a restructured geography of caring. Area 2000, $49-58$.

- 2000b: 'Breaking out of the asylum': developments in the geography of mental health the influence of the informal sector. Health and Place 6, 189-200.

Mitchell, K. 2001: Transnationalism, neoliberalism and the rise of the shadow state. Economy and Society 30, 165-89.

Mohan, G. and Mohan, J. 2002: Placing social capital. Progress in Human Geography 26, 191-210.

Mohan, J. 2000: New Labour, new localism? Renewal 7(4), 56-62.

2002: Planning, markets and hospitals. London: Routledge.

--_ 2003:Voluntarism, municipalism and welfare: the geography of hospital utilization in England in the 1930s. Transactions of the Institute of British Geographers, NS 28, 56-74.

Moon, G. and Brown, T. 2001: Closing Bart's: community and resistance in contemporary UK hospital policy. Environment and Planning $D$ 19, 43-60.

Morrison, P. and Waldegrave, C. 2002: Welfare reform and the intra-regional migration of beneficiaries in New Zealand. Geoforum 33, 85-103.

Mouzelis, N. 2001: Reflexive modernisation and the third way: the impasses of Giddens' socialdemocratic politics. Sociological Review 49, 436-56.

Nativel, C., Sunley, P. and Martin, R. 2002: Localising welfare-to-work? Territorial flexibility and the New Deal for young people. Environment and Planning C 20, 911-32.

Offe, C. 1984: Contradictions of the welfare state. London: Hutchinson.

Pahl, R. 2001: Market success and social cohesion. International Journal of Urban and Regional Research 25, 879-83.

Peck, J. 2001: Workfare states. New York: Guilford Press.

Peck, J. and Theodore, N. 2001: Exporting workfare/importing welfare-to-work: exploring the politics of Third Way policy transfer. Political Geography 20, 427-60.

Philo, C., editor 2000: Theme issue on Post- 
asylum geographies. Health and Place, 6.

Pierson, C. 1998: Contemporary challenges to welfare state development. Political Studies XLVI, 777-94.

--_ 2001: Beyond the welfare state? (second edition). Cambridge: Polity Press.

Pierson, P. 1996: The new politics of the welfare state. World Politics 48, 143-79.

Pinch, S. 1997: Worlds of welfare. London: Routledge.

-_- 1998: Knowledge communities, spatial theory and social policy. Social Policy and Administration 32, 556-71.

Pollock, A. and Price, D. 2000: Rewriting the regulations: how the World Trade Organisation could accelerate privatisation in health-care systems The Lancet 356, 1995-2000.

Powell, M. and Boyne, G. 2001: The spatial strategy of equality and the spatial division of welfare. Social Policy and Administration 35, 181-94.

Putnam, R. 2000: Bowling alone: the collapse and revival of American community. New York: Simon and Schuster.

Rieger, E. and Leibfried, S. 1998: Welfare state limits to globalisation. Politics and Society 26, 363-90.

Robson, E. 2000: Invisible carers: young people in Zimbabwe's home-based health care. Area 32, 59-70.

Smart, A. and Smart, J. 2001: Local citizenship: welfare reform, urban-rural status, and exclusion in China. Environment and Planning $A$ 33, 1853-69.

Smith, D. 2000: Moral geographies: ethics in a world of difference. Edinburgh: Edinburgh University Press.

Stears, M. 1999: Needs, welfare and the limits of associationalism. Economy and Society 28, 570-89.

Sunley, P. 2000: Pension exclusion in grey capitalism: mapping the pensions gap in
Britain. Transactions of the Institute of British Geographers NS 25, 483-502.

Sunley, P., Martin, R. and Nativel, C. 2001: Mapping the New Deal: local disparities in the performance of welfare-to-work. Transactions of the Institute of British Geographers NS 26, 484-512.

Taylor, C. 2001: The geography of choice and diversity in the 'new' secondary education market of England. Area 33, 368-81. .

Taylor, C. and Gorard, S. 2001: The role of residence in school segregation: placing the impact of parental choice in perspective. Environment and Planning A 33, 1829-52.

Taylor, D. 1998: Social identity and social policy: engagements with postmodern theory. Journal of Social Policy 27, 329-50.

Taylor-Gooby, P. 1997: In defence of second-best theory: state, class and capital in social policy. Journal of Social Policy 26, 171-92.

Thomson, K. 2002: Regional welfare system development in Russia: community social services. Social Policy and Administration 36, 105-22.

Turner, B. 2001: The erosion of citizenship. British Journal of Sociology 52, 189-209.

DeVerteuil, G., Woobae, L. and Wolch, J. 2002: New spaces for the local welfare state? The case of General Relief in Los Angeles County. Social and Cultural Geography 3(3), 229-46.

Wolch, J. and Dinh, S. 2001: The new Poor Laws: welfare reform and the localisation of help. Urban Geography 22, 482-89.

Wolch, J. and DeVerteuil, G. 2001: New landscapes of urban poverty management. In May, J. and Thrift, N., editors, Timespace: geographies of temporality, London: Routledge, 149-68.

Wolpert, J. 1996: What charity can and cannot do. New York: Twentieth Century Fund. 
Copyright $\odot 2003$ EBSCO Publishing 